\title{
Phenomenon of the Cultural Policy Influence on the Urban Environment Formation in Modern Humanitarian Studies
}

\author{
Vladimir S. Luzan* \\ Siberian Federal University \\ 79 Svobodny, Krasnoyarsk, 660041, Russia
}

Received 03.02.2016, received in revised form 26.02.2016, accepted 08.04.2016

In the course of globalization processes the theory and practice of socio-economic relations in modern world shows that cities will play a key role in the development of state and interstate associations in present and near future. In the current situation the process of globalization not only makes the borders between countries and cultures permeable, but also increases the need to fix local identity connecting people with a place of their life. As a result, the desire of municipal authorities and urban communities to form an attractive, safe and innovative city environment primarily by means and mechanisms of cultural policy is absolutely justified.

The article states that the cities, being models created by man, involve introduction of such forms of development of their own environment which would improve public relations, make urban life more comfortable and better. At that urban environment is not so much physical but symbolic, that is primarily due to various mechanisms of human self-realization and cultural identity formation.

The author emphasizes that cultural policy plays a decisive role in these processes as these are culture and cultural industries that make it possible to express values, form the citizens' cultural identity and contribute to their creative and economic wealth. Moreover, by means of cultural diplomacy the city may significantly expand the area of influence, while receiving not only cultural but also politicaleconomic dividends.

Keywords: cultural policy, cultural diplomacy, cultural industries, culture, cultural identity, urban environment, city.

DOI: 10.17516/1997-1370-2016-9-6-1521-1532.

Research area: culture studies.

\section{Introduction}

to the research problem

In the course of globalization processes the theory and practice of socio-economic relations in modern world shows that cities will play a key role in the development of state and interstate associations in present and near future. In the current situation the process of globalization not only makes the borders between countries and cultures permeable, but also increases the need to fix local identity connecting people with a place of their life. Under these conditions, the role of the cities is crucial as, according to the UNO data, the process of a substantial increase

(C) Siberian Federal University. All rights reserved

* Corresponding author E-mail address: vladimir_luzan@list.ru 
in urban population does not stop nowadays: more than half of the world's population lives in cities and by 2050 the urban dwellers' number will have increased by 2.5 billion people. At that, about half of 3.9 billion urban dwellers live in relatively small settlements with a number of inhabitants up to 500 thousand. Only every eighth citizen lives in one of the 28 global megalopolises with the population over 10 million people. Many of the fastest growing cities in the world are relatively small urban settlements [Website of the UNO information centre]. As a result, the desire of municipal authorities and urban communities to form an attractive, safe and innovative city environment primarily by means and mechanisms of cultural policy is absolutely justified.

These processes are typical for the Russian Federation. As of January 1, 2014, the share of urban population in Russia is $74,2 \%$, whereas the number of cities with the population exceeding a million people is only 15 units ["Cities of Russia" Internet portal]. This is largely due to the fact that, compared to a rural settlement, the city, to a greater degree, makes it possible for the citizens to realize their potential and opportunities. Moreover, the city is an educational, culturaland-political and information centre integrating major production and intellectual potential of the state.

When the cities are impetuously transformed into agglomerations, their spatial structure is also transformed. This causes the change in lifestyle of their citizens. That is why it is especially important nowadays to pay attention to planning and development of the urban environment as its image in the citizens' consciousness has a significant impact on them. Intensive urban development results in new forms of human behavior, their personal characteristics; it raises the problem of interaction between a human and his / her environment.
Inner-city identity is formed only in case of diversity of socio-cultural practices, services, processes in the same territory. The city must understand not only its current realities but also do everything possible in order not to lose its historical memory. Thus, this is one of the objectives of cultural policy, the objective being building the future while preserving the historical memory. In addition, it is culture that has the potential to express values and form cultural identity. Modern city is a city where creativity and an individual's self-realization become the basis of everything. The human mind, desires, motives, imagination and creativity are a strategic reserve of urban development. Conditions for people's self-expression are created on the first level; opportunities to create real production and services appear on this basis on the second level. Creation of attractive innovative urban environment, formation of the market services influencing the quality of life are the most important elements of modern life that can be realized through the cultural policy only.

It is culture in its sign-and-symbolic forms that keeps, increases and translates the entire collective human experience created in various fields of activity. Culture reflects a specific character of different social groups and, while uniting makes it possible to create attractive and innovative urban environment, to foster love and respect for the city, the country, to form a range of socio-cultural services. All these undoubtedly favour a more successful city development in all aspects.

Properly organized urban environment, in its turn, contributes to the development of the citizens' interest and, thereby, causes a feeling of comfort, safety, and desire to live and develop. However, disorderly, chaotic urban environment without some certain well-built structure, on the contrary, makes the citizens tired of their monotonous life and information overload, thus 
causing psychological stress and discomfort. That is why proper organization of urban environment is essential for the citizens' comfortable existence in the local aspect and development of the state in the global one.

\section{Conceptual basis of the research}

In modern Russian humanitarian research there are a sufficient number of papers on the perspectives of establishing cultural policy at the state level: P.S. Gurevich, V.K. Egorov, V.Zh. Kelle, L.N. Kogan, D.S. Likhachev, E.S. Markarian, V.M. Mezhueva, A.K. Uledova, U.Iu. Fokht-Babushkin, etc.

A wide range of problems concerning culture functioning in modern society is focused upon in the works of the authors forming a modern idea of culture as a factor of socio-cultural regulation of social life: M.B. Gnedovskii, N.G. Denisova, B.S. Erasova, L.G. Ionina, M.S. Kagan, V.A. Kurennoi, B.K. Markov, E.A. Orlova, M. Pakhter, A.Ia. Flier, N.A. Khrenov, I.G. Iakovenko, et al.

Besides, in the context of the issue under consideration the works on the problems of functioning of the sphere of culture, its legal, institutional, financial and managerial aspects are considered to be significant: T.V. Abankina, G.M. Galutsky, O.I. Genisaretsky, M. DragicevicSesic, B.S. Zhidkov, E.L. Ignatieva, A.V. Kamenets, E.L. Kudrina, K.E. Razlogov, A.Ia. Rubinshtein, B.Iu. Sorochkin, S.B. Shishkin, et al.

In recent years the issue of the state cultural policy implementation is the subject of numerous dissertations. The most significant researchers among them are A.S. Balakshin, P.L. Volk, L.E. Vostriakov, Iu.E. Ziiatdinov, M.I. Krivosheev, E.V. Kuznetsov, N.N. Kurnaia, O.P. Ponomarenko, G.A. Smirnova, S.P. Shevchukov, et al.

Many domestic researchers analyze the problem of development and formation of various aspects of urban environment today. A representative number of the researches are the studies of technical aesthetics and design. They are inseparably linked with the issues of urban environment and visual space, the researchers being P.A. Putintsev, M.M. Rusanov, A.V. Sazikov, A.Iu. Solomonov, V.B. Ustin, et al.

The researches on visual and aesthetic component of urban environment are an autonomous field of analysis. They are done by L.E. Trushina, analyzing aesthetic components of the image of the city and urban environment; K.A. Chekhovskikh, studying an aesthetic component in advertising as a factor of the society development; O.V. Konin, studying the citizens' perception of urban environment; T.V. Kashkabash, considering the urban visual communication space.

It is worth while pointing out the researches on urbanism and city planning as an autonomous block (L.S. Akhmedova, A.E. Gutnov; A.V. Ikonnikov, A.G. Rappaport).

In modern foreign humanitarian researches the issues of the cultural policy impact on the urban environment formation are profoundly analyzed. The works by R. Florida and Ch. Landry, as well as of constellations of younger American, European and Asian researchers (L. Knorr, E. Nilson, K. Kreiling, Z. Taylor, et al.) should be particularly mentioned. At that it is necessary to state a significant increase in publications on this issue in international scientific journals in the course of the past five years.

\section{Problem statement}

In a situation of constant changes both at global and All-Russian levels the problem of the formation of All-Russian national identity and self-identification is particularly crucial as the modern era is the era of national states, formation of the nation despite the globalization processes. It is the success of the process of the unified nation formation that the future of the state, its strategic security and ideological significance depend on. 
The formation of a single nation, uniting different ethno-cultural groups, social classes and strata, is one of the most topical problems of modern Russia. In this case, the solution to the problem is possible through cultural policy, as a set of its mechanisms and tools most actively shapes the environment of human existence that determines its distinctive character. Thus, the city and its environment (since the vast majority of Russia's population is urban) play a special role in this context.

The problem under consideration is grounded by diversity and multidimensionality of cultural policy and urban environment, as well as by their inherent interaction and complementarity. Urban environment is perceived by a man via his / her external characteristics as well as his /her mental map that is a kind of a specific atmosphere filled with numerous meanings and values that the city is full of and that form its uniqueness, a certain language. Thus, urban environment is not so much its physical filling with the buildings and other constructions and structures but a combination of various sources of information.

Due to the uniqueness of their environment, the cities can rightly be considered unique, with their own special "language", symbolic filling that is being formed over the years. This is especially relevant for Russian cities due to external and internal conditions as well as cultural vectors of evolution. According to A.Iu. Sogomonov, a leading researcher of the Sociology Institute of the Russian Academy of Sciences, "at first glance they (the cities) seem extremely similar to each other (a severe Soviet heritage of rapid urbanization) but their urban quality significantly varies from one case to another. This is primarily about the "genius of the place" and social traditions. It is undoubtedly this paradox of modern Russian urbanism which makes the search for urban identity much more currently central in most other countries where the cities' historical appearance was formed long ago and even strengthened over the years (it was not blurred as in the Soviet Union in the 19201950-ies). It is apparently not accidental that the image of cities is so actively being talked about today. What is especially noteworthy is that the cities are regarded as brands" (Sogomonov, 2010, p. 250).

A citizen, residing and existing in urban space, is also one of its main elements. However, due to his / her specificity the changes, that he / she exposes to the space around him / her, consequently result in changes in his / her life. Therefore, by changing the citizens' urban environment through the cultural policy the urban community acquires its own local identity.

\section{Discussion}

In contemporary Russian researches the current debate about the concept of "cultural policy" is presented with a range of opinions and approaches. So, D.L. Spivak links cultural policy with the activities of the state and defines it as "the sum-total of multilevel conceptual models that represent the present, past and future states of national culture in static, comparative-and-static and dynamic aspects, the states being targeted at the perspective of short-, medium-, and in some cases long-term horizons in the form of a range of scenarios from pessimistic and/or optimistic to undesirable and/or desirable ones. The models also specify the optimal tactics and strategies for the implementation of the latter by means or assistance of the whole arsenal of the state bodies' and administrations' control actions" (Fundamental'nye problemy kul'turologii, 2008, $5)$.

D. Klish in his article "Culture, Management and Regulation" emphasizes that "cultural policy should not be regarded as a prerogative of the government because it depends on many environmental factors, state agencies as well as on 
institutions of civil society and different groups of people" (Klish, 2002, 274). This understanding of cultural policy expands its interpretation compared to the state cultural policy. It indicates that not all the opportunities of state management can be implemented in cultural policy which is determined not only and not so much by such a subject as the state as numerous social groups and social processes, including those that have a form of civil society institutions.

In the definition suggested by Augustin Girard and Genevieve Gentil, French researchers in the field of cultural policy, the "cultural policy" term is regarded from the point of view of not only goals but also the states of institutions and resources: "The policy is a system of interrelated goals, practical objectives and means chosen by an expert and aimed at a certain group in society. Cultural policy can be implemented through associations, parties, educational movement, organizations, enterprises, cities, and the government. But regardless of the subject of the policy it assumes the existence of long-term goals, medium-term and measurable goals and means (human resources, finances and legislation basis), joined into an extremely complex system" (Lavrinov, 2010).

The definition of cultural policy given by A.Ia. Flier is relevant and methodologically significant in the current scientific discussion. Considering cultural policy in the context of the problem of the cultural processes management, this domestic researcher states that cultural policy is "a combination of science-based views and activities on a comprehensive social-and-cultural modernization of the society and structural reforms throughout the system of culture producing institutions, a system of new principles of the state and public components proportioning in social and cultural life, a set of measures for the early establishment of scientific and educational support of these principles, purposeful training of the professionals for a competent regulation of social and cultural processes of tomorrow, and, most importantly, a sensible adjustment of the general content of the national culture" (Flier, 2000, 20).

Thus, the following definition of cultural policy can be suggested as its synthetic definition: cultural policy is a system of human activities including clearly stated goals, effective methodology for their implementation, real actions on the creation, preservation and translation of the most significant cultural ideals (standards) and their implementation in the sociocultural reality.

This definition of cultural policy avoids its identification only with the activities of the state and suggests that the source of cultural policy is an objectively existing social process which is implemented by different social subjects.

However, in Russian reality understanding of cultural policy is based on the empirical interpretation of culture which is associated with the practice of educational activities as well as "gathering" and study of historical and cultural materials of a folklore-and-ethnographic character.

Thus, it is possible to record a certain gap between the empirical understanding of culture in branch logic and the theoretical understanding of culture as the most important sphere of human activities for creation, translation and preservation of the ideals of a twofold economic-spiritual nature. This gap also has its own form at the level of real cultural policy when the introduced concepts, strategies, target programmes, state projects affect only the content, which is related to amateur performances, folklore and ethnographic movements, historic and cultural monuments, artistic and educational activities, etc.

Moreover, fuzziness of the cultural sphere boundaries even in the context of its appliedresearch understanding is a major problem. There 
are traditional cultural institutions tied with the applied-research approach to culture. These are museums, theatres, libraries, cultural institutions, concert halls, architectural monuments. For most people they are mainly associated with the concept of "culture". However, nowadays the branch of "culture" is impossible without publishing, cinematography, recording, computer games production, design, architecture, fashion, radio and television.

Thereby, a number of researchers introduce such concepts as "cultural environment", "cultural space", "culture of life support", etc., implying a number of the individuals' and social groups' specific (cultural) terms of existence, formation and activity. They state that cultural environment is increasingly transformed by such institutions as night clubs, bookstores, festivals or new technologies (such as the Internet, for example).

Thus, a number of approaches to cultural policy enunciate the need to impose a restriction on the sphere of usage of cultural policy by the elements of the human cultural environment, which is especially important in the context of the issue of the cultural policy impact on urban environment which can be described as a type of cultural environment. The elements of the human cultural environment are considered to be ones that lend themselves to managing by the institutional mechanisms of environmental impact.

According to A. Arnol'dov (Arnoldov, 2004, 25), cultural environment represents a set of objects surrounding a human - things, ideas, images, activity patterns, behavior and interaction. Every person belongs to a certain cultural environment. It is a focus of his / her own interests and needs. Environmental parameters ultimately determine a human's qualities and characteristics. His / her entire existence in the society is existence in cultural environment, creating a certain lifestyle which also reveals the system of human relations. Cultural environment is a peculiar source of many-sided impact on various aspects of human socialization, at the same time being a personality's sphere of selfdetermination and self-realization.

Thus, it can be concluded that cultural policy nowadays is studied in accordance with the principles of social constructivism. Determination of principles, forms, ways of implementation, as well as methods, setting the goals, cultural policy projects are the signs of a possibility to change people's social life, its qualitative improvement primarily in urban areas. This situation is due to several objective factors, the factors being concentration of human, material, financial and other resources; infrastructure development; location at the intersection of transport routes (road, air, sea, rail ones); a special type of culture.

Each city has its own unique "language", presented not only by its architectural appearance but also the way of organizing space through which a certain symbolic-and-sign system as well as a cultural text read by the city's residents can be reconstructed.

Thus, urban environment, specified by the presence of a variety of different sources of information, is a carrier of a symbolic nature more than of its material content.

Thus, urban environment is meant to be the place where communication or interaction between various subjects takes place according to the rules, having their own individual nature only for a particular city. Generally the researchers distinguish the following main elements of urban environment that are the most relevant for Russian cities:

1. The city's cultural and historical uniqueness;

2. The urban landscape variety;

3. The city's infrastructural comfort; 
4. Safety of residence;

5. Environmental safety;

6. A variety of leisure activities and a possibility to obtain the maximum range of services (consumers market and socio-cultural services market development);

7. The city management quality.

In addition to physical space, forming urban environment, it is necessary to distinguish such types as:

1. Social space;

2. Cultural space;

3. Information space;

4. Communication or communicative space;

\section{Media space.}

Today, basing on cultural and social space, many humanitarian studies single out a sociocultural space of the city, which reflects the changes in human thought under the influence of political, socio-economic and cultural processes. According to A.N. Bystrova, "this is a space of human "virtuality" realization (realization of human "virtuality" implies human inclinations, possibilities, abilities, desires, etc.), implementation of social programmes, goals and interests, dissemination of ideas and opinions, language and traditions, beliefs and norms, etc." (Bystrova, 2004, 39).

The impact of these processes on modern city's environmental changes is, first of all, expressed in the destruction of standards and models of urban life that have emerged during the previous decades as well as in the change of attitudes in the system of the citizens' value orientations and ways of implementation of daily practices that can be possible only through cultural policy.

In modern Russia there are examples of successful transformation of urban environment, and, consequently, the image of the cities through the implementation of a well thought-out cultural policy in non-sectoral understanding of the term but in its understanding as a social process. For example, a small town Myshkin on the Volga River became known thanks to its name and competent policy in the promotion of a mouse, the city brand, as well as of everything associated with it (the Mouse Museum, mouse toys and souvenirs, etc.). This favoured the city's involvement in the existing tourist routes.

Over the last 15 years of active development and promotion of "Veliky Ustyug is Father Frost's homeland" brand Veliky Ustyug has become one of the popular places of rest of the Russians, and the number of tourists increases every year, especially due to external factors, such as the prohibition to have a rest in some international resorts.

The city of Yaroslavl has also significantly changed to its 1000 -year anniversary. The media strengthened the image of a 1000 year old city with the stories about this ancient city's modern transformations. A lot of new interesting objects were built. The impact of well-built cultural policy on the urban environment formation is certainly the most representative on the example of Moscow, Saint-Petersburg, Kazan, and Sochi.

At the same time, in foreign practice there are much more examples of successful changes in urban environment by the cultural policy tools, the fact being reflected in the researchers' works. However, it should be realized that more productive practices in Western countries become possible, primarily, due to a greater cultural-historical "maturity" of urban settlements, whereas in Russian reality the number of relatively young cities, especially beyond the Ural Mountains, is much larger.

At the same time, a significant difference, in our view, is that in foreign scientific discourse and practice there appears a new concept for the Russian reality. It is "cultural diplomacy". In our opinion, it terms the processes of urban transformation much more accurately, as these 
processes are not limited to internal changes of a city. They are characterized by inclusion in the global struggle for the resources (primarily human and financial ones).

Cultural diplomacy in the context of the issue under consideration should be considered as a type of public diplomacy and soft power including the exchange of ideas, information, art and other aspects of culture in human settlements, countries and among peoples to promote understanding at first glance. However, the main goal of cultural diplomacy is to influence the target audience (the population of another city, region, country or even country) and to use the influence created in the course of a long period, the influence being a sort of good will reserve to win support for the implemented policy, far beyond its cultural aspects. Thus, cultural diplomacy creates an effect and directly meets the goals of maintaining national security and conquering new zones of control.

\section{Conclusion}

Undermodernconditions, urbanenvironment formation is gaining a decisive role not only for the development of certain cities, but for the states in general. According to "McKinsey Global Institute" international consulting company, by $202560 \%$ of the world's wealth will be concentrated in top 600 cities of the world, which will be the sources of the greatest economic and demographic growth.

The city, being a model created by man, involves introduction of such forms of their own environment development, which would improve public relations, make urban life more comfortable and better in quality. At that urban environment represents not so much the physical environment as a symbolic one that is primarily due to the presence of various mechanisms of human self-realization and his cultural identity formation.

Favorable urban environment favours the desire to live, work, be creative, educate children; it generates emotional perception of the city, or, vice versa, a desire to leave the territory in search of a closer and more comfortable habitat. In this regard, the society demands for the models of urban environment development based, in particular, on the use of new technologies of information consumption.

It is undoubtedly cultural policy that plays a decisive role in these processes as the means of culture and cultural industries make it possible to express values, form the citizens' cultural identity and contribute to their creative and economic viability. Moreover, the means of cultural diplomacy lead to significant expansion of the zone of influence while receiving not only cultural but also political-economic dividends.

Thus, a modern city can be viewed as a market agent, presenting its product to the customers, and namely a set of various standards and unique high quality services, the main dividends for the city being those of maintaining the existing residents and attracting new ones. At the same time, as of today the urban environment formation in Russia is mostly understood as a city brand creation whereas in Western practice it is a systematic process encompassing all aspects of cultural policy, but not only those related to the city positioning and marketing promotion.

\section{References}

Aksoy, A., Şeyben, B.Y. (2015). Storm Over the State Cultural Institutions: New Cultural Policy Direction in Turkey, In International Journal of Cultural Policy, V. 21, I. 2, 183-199.

Ang, I., Isar, Y., \& Mar, P. (2015). Cultural Diplomacy: Beyond the National Interest?, In International Journal of Cultural Policy, V. 21, I. 4, 365-381. 
Arnol'dov, A.I. (2004). Kul'turnaia politika: realii i tendentsii [Cultural Policy: Challenges and Trends]. Moscow, $64 \mathrm{p}$.

Astaf'eva, O.N. (2010). Kul'turnaia politika: teoreticheskoe poniatie i upravlencheskaia deiatel'nost': lektsii [Cultural Policy: a Theoretical Concept and Management: lectures]. Moscow, RAGS, 228 p.

Aubry, A., Blein, A., \& Vivant, E. (2015). The Promotion of Creative Industries as a Tool for Urban Planning: the Case of the Territoire de la Culture et de la Création in Paris Region, In International Journal of Cultural Policy, V. 21, I. 2, 121-138.

Balakshin, A.S. (2006). Kul'turnaia politika: teoriia i metodologiia issledovaniia: dis. ... d-ra filos. nauk [Cultural Policy: Theory and Methodology of the Study: Thesis of Doctor of Philosophy]. N. Novgorod, $358 \mathrm{p}$.

Bystrova, A.N. (2004). "Kul'turnoe prostranstvo kak predmet filosofskoi refleksii” ["Cultural Space as a Subject of Philosophical Reflection"], In Philosophical Sciences, 12, 39.

Carter, D. (2015). Living with instrumentalism: The Academic Commitment to Cultural Diplomacy, In International Journal of Cultural Policy, V. 21, I. 4, 478-493.

Caust, J. (2015). Cultural Wars in an Australian Context: Challenges in Developing a National Cultural Policy, In International Journal of Cultural Policy, V. 21, I. 2, 168-182.

Chaney, P. (2015). Parties, Promises and Politics: Exploring Manifesto Discourse on Arts Policy in Westminster, Scottish, Welsh and Northern Irish Elections 1945-2011, In International Journal of Cultural Policy, V. 21, I. 5, 611-630.

Flier, A.Ia. (2000). Kul'turologiia dlia kul'turologov [Culturology for Culturologists]. Moscow, Akademicheskii proekt, $496 \mathrm{p}$.

Florida, R. (2007). Kreativnyi klass: liudi, kotorye meniaiut budushchee [Creative Class: People Who Change the Future]. Moscow, Publishing House "Klassika XXI", 432 p.

Fundamental'nye problem kul'turologii [Fundamental Problems of Cultural Studies] . (2008). Sbornik statei po materialam kongressa: v 4 t. T. 4: Kul'turnaia politika [Congress materials in 4 vol. Vol. 4: Cultural Policy]. St.-Petersburg, Aleteiia, 423 p.

Galutskii, G.M. (1998). Upravliaemost' kul'tury i upravlenie kul'turnymi protsessami [Controllability of Culture and Cultural Processes Management]. Moscow, $464 \mathrm{p}$.

Gnedovskii, M. (2005). Tvorcheskie industrii: politicheskii vyzov Rossii [Creative Industries: a Political Challenge of Russia], In Otechestvennye Zapiski [Domestic Notes], 4 (25), 168-181.

Hesmondhalgh, D., Nisbett, M., Oakley, K., \& Lee, D. (2015). Were New Labour's cultural Policies Neo-Liberal? In International Journal of Cultural Policy, V. 21, I. 1, 97-114.

Isar, Y.R. (2015). 'Culture in EU External Relations': An Idea Whose Time Has Come? In International Journal of Cultural Policy, V. 21, I. 4, 494-508.

Ivliev, G.P. (2012). Kul'turnaia politika i razvitie zakonodatel'stva o kul'ture v Rossiiskoi Federatsii: stat'i $i$ vystupleniia [Cultural Policy and Development of Legislation on Culture in the Russian Federation: Articles and Speeches]. Moscow, Norma, INFRA-M, 208 p.

Iwabuchi, K. (2015). Pop-Culture Diplomacy in Japan: Soft Power, Nation Branding and the Question of 'International Cultural Exchange', In International Journal of Cultural Policy, V. 21, I. 4, 419-432.

Kang, H. (2015). Contemporary Cultural Diplomacy in South Korea: Explicit and Implicit Approaches, In International Journal of Cultural Policy, V. 21, I. 4, 433-447. 
Katiuzhinsky, A., Okech, D. (2014). Human Rights, Cultural Practices, and State Policies: Implications for Global Social Work Practice and Policy. International, In Journal of Social Welfare, V. 23, I. $1,80-88$.

Klish, D. (2002). Kul'tura, upravlenie i regulirovanie [Culture, Management and Regulation], In Kul'turologiia [Cultural studies]. Moscow, 274.

Koptseva, N.P. (2012a). Kul'turnaia baza formirovaniia obshcherossiiskoi natsional'noi identichnosti v Sibirskikh regionakh Rossiiskoi Federatsii [The Cultural Basis All-Russian National Identity Formation in Siberian Regions of the Russian Federation], In Science Journal of Volgograd State University. Series 7. Philosophy, Sociology and Social Technologies, 3, 11-15.

Koptseva, N.P. (2012b). Metodologicheskie vozmozhnosti sotsial'noi (kul'turnoi) antropologii dlia sovremennykh kul'turnykh issledovanii [Methodological Opportunities for Social (Cultural) Anthropology for Contemporary Cultural Studies, In Filosofiia i kul'tura [Philosophy and Culture], 10, 9-18.

Koptseva, N.P., Luzan V.S. (2012). Gosudarstvennaia kul'turnaia politika v Sibirskom federal'nom okruge: kontseptsii, problemy, issledovaniia [State Cultural Policy in the Siberian Federal District: Concepts, I.s, Research]. Krasnoyarsk: Publishing House of SibFU, 160 p.

Kreativnaia laboratoriia: dialog tvorcheskikh praktik [Creative Laboratory: The Dialogue of Creative Practices] (2009). Moscow, Academic Project, 476 p.

Lavrinova, N.N. Sushchnost' kul'turnoi politiki [The Nature of Cultural Policy]. Available at: $\mathrm{http} / / /$ analiculturolog.ru/component/k2/item/229-article_41.html (accessed 15 January 2016).

Lee, H. (2015). Branding the Design City: Cultural Policy and Creative Events in Seoul, In International Journal of Cultural Policy, V. 21, I. 1, 1-19.

Lemasson, G. Cultural Development: a New Policy Paradigm in the Cultural Policies of the 1970s in Québec, In International Journal of Cultural Policy, V. 21, I. 5, 593-610.

Landry, Ch. (2011). Kreativnyi gorod [Creative City]. Moscow, Publishing House "Klassika XXI", 399 p.

Luzan, V.S. (2009). Kul'turnaia politika kak samostoiatel'nyi vid gosudarstvennoi politiki [Cultural Policy as a Self-Independent Type of State Policy], In Journal of Siberian Federal University. Series 2. Humanities, 4, 587-594.

Luzan, V.S. (2011). Sotsio-filosofskii analiz dinamiki gosudarstvennoi kul'turnoi politiki Rossiiskoi Federatsii: Avtoreferat dis. ... kand. filos. nauk [Socio-philosophical analysis of the dynamics of the state cultural policy in the Russian Federation: author's abstract of doctoral dissertation in Philosophy]. Krasnoyarsk, $26 \mathrm{p}$.

Luzan, V.S. (2013). Konteksty ponimaniia intellektual'nogo dosuga v sovremennykh rossiiskikh issledovaniiakh [The Contexts of Intellectual Leisure Understanding in Contemporary Russian Studies], In Bulletin of Krasnoyarsk State Pedagogical University named after V.P. Astafiev, 4 (26), 175-178.

Ofitsial'nyi sait OON [The Official Website of the UNO Information Centre]. Available at: http:// www.unic.ru/press/po-dannym-oon-uvelichivaetsya-gorodskoe-narodonaselenie-segodnya-boleepoloviny-naseleniya-mir (accessed 15 January 2016).

Rimkute, A. (2014). The Transition from State to Arm's Length Cultural Policy in Lithuania, In Transformations in Business and Economics, V. 13, I. 1, 209-222. 
Rius Ulldemolins, J., Zamorano, M.M. (2015). Spain's Nation Branding Project Marca España and Its Cultural Policy: the Economic and Political Instrumentalization of a Homogeneous and Simplified Cultural Image, In International Journal of Cultural Policy, V. 21, I. 1, 20-40.

Sogomonov, A.Iu. (2010). Sovremennyi gorod: strategiia identichnosti [Modern City: the Strategy of Identity], In Neprikosnovennyi Zapas [Emergency Reserve], 2 (70), 244 - 254.

Su, W. (2014). Cultural Policy and Film Industry as Negotiation of Power: The Chinese State's Role and Strategies in Its Engagement with Global Hollywood 1994-2012, In Pacific Affairs, V. 87, I. 1, 93-114.

Su, W. (2015). From Culture for the People to Culture for Profit: the PRC's Journey Toward a Cultural Industries Approach, In International Journal of Cultural Policy, V. 21, I. 5, 513-528.

The Internet Portal "The Cities of Russia”. Available at: http://города-россия.pф (accessed 1 January 2016).

Vojtíšková, K., Lorencová, R. (2015). Public Funding of Culture in the Czech Republic since the Fall of the Iron Curtain: Contemporary Dilemmas, In International Journal of Cultural Policy, V. 21, I. 5, 529-553.

Vostriakov, L.E. (2005). Regional'naia kul'turnaia politika poreformennoi Rossii: sub'ektnoi izmerenie [Regional Cultural Policy of Post-Reform Russia: Subjective Dimension]. St.Petersburg, SZAGS, $344 \mathrm{p}$.

Zamorano, M.M., Rodríguez Morató, A. The Cultural Paradiplomacy of Barcelona since the 1980s: Understanding Transformations in Local Cultural Paradiplomacy, In International Journal of Cultural Policy, V. 21, I. 5, 554-576.

\section{Феномен влияния культурной политики на формирование городской среды в современных гуманитарных исследованиях}

В.С. Лузан

Сибирский федеральный университет Россия, 660041, Красноярск, пр. Свободный, 79

\footnotetext{
В условиях глобализационных процессов теория и практика соииально-экономических отношений в современном мире показывает, что ключевую роль в развитии государств и межгосударственных объединений в настоящем и ближайшем будущем будут играть города. Сложившаяся ситуация связана с тем, что процесс глобализаиии не только делает проницаемыми границы между странами и культурами, но и усиливает потребность в фиксации локальной идентичности, связывающей людей с местом их жизни. В результате совершенно обоснованным является стремление муниципальных властей и городских сообществ в формировании привлекательной, безопасной и нестандартной городской среды, в первую очередь средствами и механизмами культурной политики.

В статье отмечается, что город, выступающий в качестве модели, созданной человеком, предполагает внедрение таких форм развития собственной среды, которые бы позволили усовершенствовать общественные отночения, сделать городскую жизнь более качественной и комфортной. При этом городская среда представляет собой не столько физическое
} 
окружение, сколько символическое, которое, прежде всего, обусловлено наличием разнообразных механизмов самореализации человека и формирования его культурной идентичности.

Автор подчеркивает, что определяющую роль в данных процессах играет культурная политика, так как именно средствами культуры и культурных индустрий возможно выражать ценности, формировать культурную идентичность жителей и способствовать их творческой и экономической состоятельности. Более того, средствами культурной дипломатии городу возможно существенно расширить зону собственного влияния, получая при этом дивиденды не только культурного, но и политико-экономического плана.

Ключевые слова: культурная политика, культурная дипломатия, культурные индустрии, культура, культурная идентификачия, городская среда, город.

Научная специальность: 24.00.00 - культурология. 